\title{
PERCEIVED LEARNING OUTCOMES AND TEAM BEHAVIOR IN ENTREPRENEURIAL VENTURE CREATION UNIVERSITASCIPUTRA SURABAYA 2020
}

\author{
Yuanita Ratna Indudewi \\ School of Management and Business, International Business Management, \\ febe.yuanita@ciputra.ac.id
}

\begin{abstract}
Entrepreneurial Venture Creation is one of signature curricula in International Business Management UniversitasCiputra Surabaya. It is part of 7 semesters Entrepreneurship Education Journey to equip students with entrepreneurial skill by doing real business project. It is a set skill that helps students to face volatile, uncertain, complex and ambiguous (VUCA) future. Especially during COVID-19, it's one of a real case study of VUCA. During Entrepreneurial Venture Creation (EVC), students guided through design thinking phase starting from empathize, defining problem, ideation and prototyping, market testing, finally they evaluate and conclude their venture development. Half of the design thinking process of EVC was done remotely in an online classroom platform due to COVID-19. The purpose of this research is to evaluate whether Entrepreneurship Education intervention in form of Entrepreneurial Venture Creation curricula can increase their perceived knowledge, perceived entrepreneurial mindset, and perceived venture creation skill. This study also want get a closer understanding how team behavior can interfere their venture continuation. There are 533 of second semester students who were participated in the survey. Total population sampling was used in the process. Quantitative method was used in the process of analyzing data. The result of simple statistic descriptive showed they have positively increased their perceived entrepreneurial knowledge, perceived entrepreneurial mindset and perceived venture creation skill, whether they have a good team behavior or not. The statistic showed that there are 9.19\% teams that didn't have good behavior and decided to discontinue their venture, yet still have high perceived entrepreneurial knowledge, perceived entrepreneurial mindset, and perceived venture creation skill.
\end{abstract}

Keywords: Entrepreneurship Education, Venture Creation, Entrepreneurial Skill.

ABSTRAK
Entrepreneurial Venture Creation merupakan salah satu kurikulum kewirausahaan utama di
International Business Management Universitas Ciputra Surabaya.Program pendidikan kewirausahaan selama 7
semester ini bertujuan untuk membekali mahasiswa dengan kemampuan berwirausaha dengan melakukan
proyek bisnis yang sesungguhnya.Kurikulum ini diharapkan mengembangkan keterampilan yang akan
membantu siswa untuk menghadapi masa depan yang tidakpasti, kompleks, dan ambigu (VUCA). Masa
pandemic COVID-19 adalah salah satu studi kasus nyata terjadinya VUCA.Pada perkuliahan Entrepreneurial
Venture Creation (EVC), mahasiswa dibimbing melalui tahapan design thinking mulai dari berempati,
mendefinisikan masalah, ide asi dan prototyping, serta uji pasar. Pada akhir perkuliahan, para mahasiswa
mengevaluasi dan menyimpulkan hasil validasi model bisnis mereka.Setengah dari proses perkuliahan EVC
dilakukan dari jarak jauh di platform ruang kelas online karena COVID-19. Tujuan dari penelitian ini adalah
untuk mengevalua siapakah intervensi Pendidikan kewirausahaan dalam bentuk kurikulum Entrepreneurial
Venture Creation dapat meningkatkan pengetahuan yang dipersepsikan, pola piker kewirausahaan yang
dipersepsikan, dan keterampilan penciptaan usaha yang dipersepsikan. Studi ini juga ingin lebih memahami
bagaimana perilaku tim berdampak terhadap kelangsungan usaha mereka. Ada 533 mahasiswa semester dua
yang mengikuti survei.Penelitian ini menggunakan metode kuantitatif dalam proses pengolahan dan analisis
data. Total sampel populasi atau sampel jenuh digunakan dalam proses ini. Hasil deskriptif statistik sederhana


menunjukkan bahwa mereka secara positif meningkatkan persepsi pengetahuan kewirausahaan, pola piker kewirausahaan dan keterampilan penciptaan usaha yang dipersepsikan, baik mereka memiliki perilaku tim yang baik maupun tidak. Statistik menunjukkan bahwa ada 9,19\% tim yang tidak berperilaku baik dan memutuskan untuk menghentikan usahanya, namun masih memiliki persepsi pengetahuan kewirausahaan yang tinggi, pola piker kewirausahaan yang dirasakan, dan keterampilan penciptaan usaha yang dipersepsikan.

Keywords: Entrepreneurship Education, Venture Creation, Entrepreneurial Skil

\section{A. Introduction}

Seow, Pan, \&Koh (2019) argue that "Due to the constantly changing work environment, there is a need for universities to produce students who can adapt in a volatile, uncertain, complex and ambiguous (VUCA) work environment."VUCA has presented itself in the form of Covid-19 in 2020. World Health Organization (WHO) declared COVID-19 as a global public health emergency of international concern on 30th January 2020 as well as a pandemic on 11th March 2020 (Cucinotta\&Vanelli, 2020). First COVID-19 case in Indonesia made headlines in $2^{\text {nd }}$ March 2020. It went spiral after the first case confirmed until this very moment. No one see Covid-19 coming and how it can turn into a worldwide pandemic. All the business plan, travel and tourism industry went downhill in an instance. This is the most real example of VUCA world. The COVID-19 pandemic forced universities to switch their entire instructional apparatus to one of online delivery overnight (Liguori\& Winkler, 2020), and UniversitasCiputra Surabaya is one of the university that change the whole course into online class within a week. One of the course impacted by this, is Entrepreneurial Venture Creation, which is part of 7 semester Entrepreneurship Education curricula for second semester International Business Management students. Entrepreneurial Venture Creation is a 16 weeks lesson plan to enable students to validate business models in groups by considering the 4 pillars of business management and technological aspects in establishing a start-up business. Meanwhile, online entrepreneurship education according to several studies has failed to improve the perceived value of entrepreneurship education, in part because approaches to entrepreneurship education emphasize the need for deliberate practice, realworld immersion, and experiential approaches (Kassean et al., 2015; Neck et al., 2014). The pedagogical approaches has been historically proven many times need face-to-face offline classroom situation to work (Morris \&Liguori, 2016). Other argue that, relatively little is known with regard to the impact and effectiveness of online learning (McPherson \&Bacow, 2015), with even less known within the context of entrepreneurship education.Considered all those previous studies and pandemic condition, this study is important to evaluate whether Entrepreneurship Education intervention in form of Entrepreneurial Venture Creation using online platform still able increase students perceived knowledge, perceived entrepreneurial mindset, and venture creation skill. The study once again highlight that half of semester of Entrepreneurial Venture Creation was done fully online due to COVID-19. The study also gets a closer understanding how students' team behavior works in the middle of online/distance learning situation.

\section{8 | P a g e}




\section{B. Literature Review}

\section{Entrepreneurship Education}

Adhikusuma and Genoveva (2018), referencing Rae in 2010 beliefs that being an Entrepreneurs shaped by the existence of a good education.Proper entrepreneurship education provides basic insight on how to be an entrepreneur within the entrepreneurial network. The main role of entrepreneurship education is to increase student mindfulness and to highlight the entrepreneurial pathas a reasonable vocation alternative (Fayolle and Klandt, 2015). Past references on entrepreneurship education suggests a various potential entrepreneurial learning outcomes for entrepreneurship programmes (Hytti et al., 2010). The required learning outcomes canbe obtained from extensiveentrepreneurship education goals. There are three three distinct kinds of objectives in entrepreneurship education: expanding the knowledge base in entrepreneurship (about entrepreneurship), building up the pioneering or venturesome aptitudes of understudies (through entrepreneurship) or starting up a new venture (for entrepreneurship). In the higher education setting it is imperative to accentuate both the knowledge base and the skills needed to create, develop and grow ventures. Entrepreneurship education provides enormous opportunities to university students to extend their insight of entrepreneurship while providing significant learning encounters (Othman \& Othman, 2017).

The viability of entrepreneurship education: Effective implementation of entrepreneurship education in universities can increase student's impression of entrepreneurship (Othman \& Othman, 2017). Fayolle and Klandt (2015), consider effective entrepreneurship education should gauge its pedagogical, both at the design level and at program implementation level. Fatoki and Oni (2014) stated that entrepreneurship education is effective in certain aspect such as urging understudies to choose entrepreneurial careers and master entrepreneurial skills such as preparing marketable business model. Morris and Liguori (2016) offer three categories in entrepreneurship education focus. Those are business knowledge, entrepreneurship basics, and entrepreneurial mind-set and competencies. Based on all of the literature, the perceived learning outcome to measure the effectiveness of Entrepreneurial Venture Creation curriculum, divided into three categories of entrepreneurial knowledge (business knowledge), entrepreneurial mind-set, and entrepreneurial skills. The overall Entrepreneurial Venture Creation student's satisfaction rate at the end of the semester was around 4,5 out 5 range.Students rate facilitators and the overall class process meet their needs to become an entrepreneur.

\section{Project Based Learning}

Entrepreneurship Education most likely used project based learning as pedagogical method to deepen students' knowledge of entrepreneurship while providing valuable learning experiences. Project-based learning helps students exposed to substantive in-class knowledge to build a strong foundation essential for contribution to the real, unresolved problem in the form of a real world project (Seow, Pan, \&Koh, 2019). Seow, Pan, \&Koh (2019) believes that project based learning accelerate students' learning to immerse into the real world and exposes students to the uncertainty and ambiguity of real world issues. The Entrepreneurial

\section{9 | P a g e}


Venture Creation use project based learning from time to time and this is the first time that half of the project based learning course done fully online.

\section{Design Thinking}

Dunne and Martin (2006) proposed design thinking as a cycle and something that could be instructed to everybody. Design thinking seen as an equally significant user-centred approach, relational aptitudes from joint effort with peers is vital to developing a mutual understanding around a commonly agreed up set of facts. Joint effort in this setting depends on cooperation and growing viewpoints by gaining from non-homogeneous people (Dunne \& Martin, 2006). Design thinking is very helpful in handling complex issues that are badly characterized or obscure, by understanding the human needs required, by re-outlining the issue in human-driven ways, by making numerous thoughts in meetings to generate new ideas, and by embracing an active methodology in prototyping and testing. There are five stages in design thinking, starting from empathize, defining problem, ideation and prototyping, market testing, finally evaluate and iteration. Entrepreneurial Venture Creation curriculum based on design thinking to exercise students' problem solving skill, have more human-centred approach in designing a business model, and to practice interpersonal skill with their peers. Hence, the perceived team behaviour needed to get further insight.

\section{Students' Team Behaviour}

Entrepreneurship education provides a significant factor to help students to know and pursueentrepreneurial behaviour (Cakranegara\&Runtuk, 2019) Social relationships are viewed as significant in the recognizable proof of entrepreneurial opportunities (Hytti et al., 2010). Furthermore, the role of the team has been underlined in opportunity recognition and business activities, particularly in the beginning stages of the venture (Harper, 2008). Opportunity recognition isn't just an individual cycle yet a dynamic collaboration inside the group. The information gave by the group, integral perspectives and companion weight may all contribute decidedly to the group execution. In this study, perceived team behaviour questionnaire items divided into two categories of team shared resources and team member trust and reliability.

\section{Research Method}

The research was conducted using quantitative method approach. The quantitative research approach emphasizes objective phenomena that are studied by reducing the data to numbers which are then discussed descriptively. This research will focus on quantitative methods by using a survey approach in data collection.Descriptive statistical analysis will be used in this study to measure all data and provide an understanding of the effectiveness of the Entrepreneurial Venture Creation curriculum for UniversitasCiputra Surabaya. The results of the data analysis will measure whether entrepreneurship education interventions help students to improve entrepreneurial knowledge, entrepreneurial mindset, and entrepreneurial skills.

\section{0 | P a g e}


The study also measured team behavior from students' perceptions to separate business continuity from perceived learning outcomes.

\section{Sample and Data Collection}

The overall data gathered from second semester students in International Business Management, specifically students who have taken Entrepreneurial Venture Creation course. In total, there are 533 students filled the questionnaire via google form link provided in May 2020. They filled the link at week 15 out of 16 weeks of Entrepreneurial Venture Creation course. The data collected shown the majority of respondents age is 19 years old $(53,28 \%$ out of total 533 students), meanwhile total respondents' age range from 17 to 22 years old.

During week 1 to week 15 , students expected to perform in team consist of 3 to 5 members. This team then divided in 16 classes and mentored by two class facilitators. The curriculum given was based on design thinking steps and project based learning method. They learn to empathize and define business problem and opportunity within the first three weeks. They spent the next 3 weeks to ideate their business model idea based on their business problem and opportunity. After ideation, they try to make the low resolution prototype in a week to pitch in the midterm. After midterm, they have 5 weeks to test and iterate their business model and prototype to the experts and real customers. The final 2 weeks were given to finalize their business model and prepare the soft launching of their business. This curriculum was performed in the middle of covid-19 pandemic. First half of semester performed in offline class, and the rest of the semester was performed online. The online class was performed using open source learning platform such as Moodle and several online meeting platforms such as Zoom, WhatsApp video call, or Line Messenger video call. The students were challenged to be creative to perform market testing using their family, friends, and neighbors, even online expert appointment. The questionnaires used in this study interpret based on 5 points Likert scale, where 1 is strongly disagree and 5 is strongly agree. Table-1 will generate the mean score interpretation.

Table 1. Mean Score Interpretation

\begin{tabular}{cl}
\hline Mean Score & Level \\
\hline $1.00-2.00$ & Low/Negative \\
$2.01-3.00$ & Below Average \\
$3.01-4.00$ & Moderately High \\
$4.01-5.00$ & High/Positive \\
\hline \multicolumn{2}{c}{ Source: Othman \& Othman (2017) }
\end{tabular}

Total population sampling used to generate all data we get from the students. The entire population of Entrepreneurial Venture Creation Students is 538 students, but only 533 students finished the entire course. Hence, I use the entire data sample gathered to have a better data representation. Since this study doesn't involve effects or differences, large sample didn't bias the result. This sample size consideration already based on Hair et al. principles, "a census of the entire population makes statistical inference unnecessary, because any differences or relationship, however small, is true and does exist" (Hair et al., 2006). 


\section{Measures}

Perceived Learning Outcome. Entrepreneurial Venture Creation outcome is to enable students to validate business models in groups by considering the 4 pillars of business management and technological aspects in establishing a start-up business. Self-assessed perception of the final achievement resulting from the Entrepreneurial Venture Creation course used as a measurement of Perceived learning outcome. There are 19 items in perceived learning outcome questionnaire. The questionnaire was adapted and cited from Othman \& Othman (2017). Table-2 showed that within 19 items in the learning outcome questionnaire, there are 9 items to measure students' knowledge, 5 items on mindset, and 5 items on skills.

Table 2.Perceived Learning Outcome Items

Questionnaire Items

Categories

1. EVC enhances my understanding of how to generate innovative ideas

k1

2. EVC enhances my understanding of the entrepreneurial environment

3. EVC increases my understanding of the basic principles of finance in entrepreneurship

4. EVC enhances my understanding of the business planning process

5. EVC enhanced my understanding of market research in entrepreneurship

6. EVC increases my understanding of the attitudes that need to be owned in entrepreneurship

7. EVC enhances my understanding of the importance of entrepreneurship for society and individuals

8. EVC enhances my understanding of entrepreneurial characteristics

9. EVC increases my understanding of the reasons for engaging in entrepreneurship activities

10. EVC inspires the belief that entrepreneurship is something I can do

11. EVC inspired my entrepreneurial mindset

12. EVC lecturers were able to inspire my entrepreneurial mindset

13. EVC Guest Lecturer was able to inspire my entrepreneurial mindset

14. The story of a successful local entrepreneur inspired my entrepreneurial mindset

15. EVC enhanced my ability to build networks

16. EVC increased my knowledge of how to build business models

17. EVC enhances my ability to manage business projects

18. EVC enhances my ability to handle risk and uncertainty

19. EVC improves my overall entrepreneurship skills

Source: Adaptation questionnaire items from Othman \& Othman (2017) k2

k3

k4

k5

Knowledge

k6

k7

k8

k9

m1

$\mathrm{m} 2$

m3 Mindset

m4

m5

s1

s2

s3 Skills

s4

s5 
Each of these items were translated to Bahasa Indonesia and were being tested of the validity and reliability for further use as a valid and reliable questionnaires instrument in this study. Table-3 provides the summary of the validity and reliability test result. Pearson method was used to compare the $r$ compute and the $r$ table and check each of the item validity. Reliability test from IBM SPSS Statistics 23 was used to check if the cronbachalpha of each category is more than 0.6 .

Table-3. Validity and Reliability Perceived Learning Outcome Items

\begin{tabular}{|c|c|c|c|c|c|c|}
\hline \multirow[b]{2}{*}{ Items } & \multirow[b]{2}{*}{ Categories } & \multicolumn{4}{|c|}{ Validity (N 500 respondents) } & \multirow[b]{2}{*}{ Reliability } \\
\hline & & r compute & $\begin{array}{c}\mathrm{r} \text { table } \\
\text { (Level of } \\
\text { Significance } \\
1 \% \text { ) }\end{array}$ & $\begin{array}{l}\mathrm{r} \text { table (Level } \\
\text { of } \\
\text { Significance } \\
5 \% \text { ) }\end{array}$ & Description & \\
\hline $\mathrm{k} 1$ & \multirow{9}{*}{ Knowledge } & 0.763 & 0.115 & 0.088 & Valid & \multirow{9}{*}{$\begin{array}{c}\text { Cronbach } \\
\text { alpha } 0.913 \\
>0.6, \text { all } 9 \\
\text { items are } \\
\text { reliables }\end{array}$} \\
\hline $\mathrm{k} 2$ & & 0.800 & 0.115 & 0.088 & Valid & \\
\hline $\mathrm{k} 3$ & & 0.708 & 0.115 & 0.088 & Valid & \\
\hline $\mathrm{k} 4$ & & 0.771 & 0.115 & 0.088 & Valid & \\
\hline $\mathrm{k} 5$ & & 0.770 & 0.115 & 0.088 & Valid & \\
\hline k6 & & 0.810 & 0.115 & 0.088 & Valid & \\
\hline $\mathrm{k} 7$ & & 0.775 & 0.115 & 0.088 & Valid & \\
\hline $\mathrm{k} 8$ & & 0.798 & 0.115 & 0.088 & Valid & \\
\hline $\mathrm{k} 9$ & & 0.747 & 0.115 & 0.088 & Valid & \\
\hline $\mathrm{m} 1$ & \multirow{5}{*}{ Mindset } & 0.756 & 0.115 & 0.088 & Valid & \multirow{5}{*}{$\begin{array}{c}\text { Cronbach } \\
\text { alpha } 0.849 \\
>0.6, \text { all } 5 \\
\text { items are } \\
\text { reliable }\end{array}$} \\
\hline $\mathrm{m} 2$ & & 0.803 & 0.115 & 0.088 & Valid & \\
\hline $\mathrm{m} 3$ & & 0.787 & 0.115 & 0.088 & Valid & \\
\hline $\mathrm{m} 4$ & & 0.831 & 0.115 & 0.088 & Valid & \\
\hline m5 & & 0.769 & 0.115 & 0.088 & Valid & \\
\hline s1 & \multirow{5}{*}{ Skills } & 0.785 & 0.115 & 0.088 & Valid & \multirow{5}{*}{$\begin{array}{c}\text { Cronbach } \\
\text { alpha } 0.880 \\
>0.6, \text { all } 5 \\
\text { items are } \\
\text { reliable }\end{array}$} \\
\hline s2 & & 0.823 & 0.115 & 0.088 & Valid & \\
\hline s3 & & 0.863 & 0.115 & 0.088 & Valid & \\
\hline s4 & & 0.827 & 0.115 & 0.088 & Valid & \\
\hline s5 & & 0.821 & 0.115 & 0.088 & Valid & \\
\hline
\end{tabular}

Source: IBM SPSS Statistics 23 
Perceived Team Behavior. Team behavior was measured using questionnaire developed by Hytti et al. (2010). The questionnaires consist of 15 items to indicate students' perceptions of the functioning of the student team. Out of 15 items in the questionnaires, there are 4 items to measure Team Resources and the rest 11 items to measure Team Trust and Reliability. All of these items help this study to see how students perceived their resources and how they can trust and rely to their team members. Table- 4 generates each of the item and the category.

Table-4. Perceived Team Behaviour Items

\begin{tabular}{|c|c|c|}
\hline Questionnaire Items & & Categories \\
\hline $\begin{array}{l}\text { 1. I received many new contacts from team members who were useful in starting a } \\
\text { business. }\end{array}$ & $\mathrm{r} 1$ & \multirow{4}{*}{$\begin{array}{c}\text { Team } \\
\text { Resources }\end{array}$} \\
\hline 2. Each team member has sufficient resources to get me to start a business. & $\mathrm{r} 2$ & \\
\hline 3. The skills of each of my team members are very useful in starting a business. & r3 & \\
\hline 4. Our team consists of members who have the ability to develop business ideas. & $\mathrm{r} 4$ & \\
\hline $\begin{array}{l}\text { 5. My team members didn't hesitate to help me introduce me to contacts who were } \\
\text { important for starting a business." }\end{array}$ & $\mathrm{t} 1$ & \multirow{10}{*}{$\begin{array}{l}\text { Trust and } \\
\text { Reliability }\end{array}$} \\
\hline 6. I know my team members very well. & $\mathrm{t} 2$ & \\
\hline 7. I have close relationships with the rest of the team. & $\mathrm{t} 3$ & \\
\hline $\begin{array}{l}\text { 8. I received important information from team members that was helpful in developing } \\
\text { business ideas. }\end{array}$ & t4 & \\
\hline 9. My team is made up of members who can be counted on to help me start a business. & t5 & \\
\hline 10. Team members support each other, even in difficult situations. & t6 & \\
\hline 11. Team members always try to avoid hurting the interests of other members. & $\mathrm{t} 7$ & \\
\hline 12. Team members always keep their promises. & $\mathrm{t} 8$ & \\
\hline 13. In our team nobody exploits other members even if it's possible. & t9 & \\
\hline 14. All team members have the same goals as me in starting a business. & $\mathrm{t} 10$ & \\
\hline 15. Within the team, we understand and accept the different goals between members. & $\mathrm{t} 11$ & \\
\hline
\end{tabular}

Source: Adaptation questionnaire items from Hytti et al. (2010)

Each of these items were also translated to Bahasa Indonesia and were being tested of the validity and reliability for further use as a valid and reliable instruments in this study, just like the perceived learning outcome items. Table-5 provides the summary of the validity and reliability test result. To check the validity, Pearson method was used to compare the $r$ compute and the $r$ table. IBM SPSS Statistics 23 was used to check if the cronbach alpha of each category is more than 0.6 to conclude the validity of each item.

Table-5. Validity and Reliability Perceived Team Behaviour Items

\begin{tabular}{|l|l|l|l|}
\hline & Categories & Validity (N 500) & Relibility \\
\hline
\end{tabular}




\begin{tabular}{|c|c|c|c|c|c|c|}
\hline & & r compute & $\begin{array}{c}\text { rtabel } \\
\text { (Level of } \\
\text { Significance } \\
1 \% \text { ) }\end{array}$ & $\begin{array}{c}\text { rtabel (Level } \\
\text { of } \\
\text { Significance } \\
5 \% \text { ) }\end{array}$ & Description & \\
\hline $\mathrm{r} 1$ & \multirow{4}{*}{$\begin{array}{c}\text { Team } \\
\text { Resources }\end{array}$} & 0.732 & 0.115 & 0.088 & Valid & \multirow{4}{*}{$\begin{array}{c}\text { Cronbach } \\
\text { alpha } \\
0.818> \\
0.6, \text { all } 4 \\
\text { items are } \\
\text { reliable } \\
\end{array}$} \\
\hline$r 2$ & & 0.848 & 0.115 & 0.088 & Valid & \\
\hline r3 & & 0.826 & 0.115 & 0.088 & Valid & \\
\hline r4 & & 0.818 & 0.115 & 0.088 & Valid & \\
\hline $\mathrm{t} 1$ & \multirow{11}{*}{$\begin{array}{l}\text { Trust and } \\
\text { Reliability }\end{array}$} & 0.709 & 0.115 & 0.088 & Valid & \multirow{11}{*}{$\begin{array}{c}\begin{array}{c}\text { Cronbach } \\
\text { alpha }\end{array} \\
0.944> \\
0.6 \text {, all } 11 \\
\text { items are } \\
\text { reliable }\end{array}$} \\
\hline $\mathrm{t} 2$ & & 0.768 & 0.115 & 0.088 & Valid & \\
\hline t3 & & 0.769 & 0.115 & 0.088 & Valid & \\
\hline $\mathrm{t} 4$ & & 0.820 & 0.115 & 0.088 & Valid & \\
\hline $\mathrm{t} 5$ & & 0.866 & 0.115 & 0.088 & Valid & \\
\hline t6 & & 0.888 & 0.115 & 0.088 & Valid & \\
\hline $\mathrm{t7}$ & & 0.835 & 0.115 & 0.088 & Valid & \\
\hline t8 & & 0.788 & 0.115 & 0.088 & Valid & \\
\hline t9 & & 0.761 & 0.115 & 0.088 & Valid & \\
\hline $\mathrm{t} 10$ & & 0.793 & 0.115 & 0.088 & Valid & \\
\hline $\mathrm{t} 11$ & & 0.815 & 0.115 & 0.088 & Valid & \\
\hline
\end{tabular}

Source: IBM SPSS Statistics 23

\section{Analysis}

Statistic descriptive analysis used in this study to measure all the data and give insight the effectiveness of the Entrepreneurial Venture Creation curriculum to UniversitasCiputra Surabaya Students. It's important to measure whether the entrepreneurship education intervention helps students to improve their Entrepreneurial Knowledge, Entrepreneurial Mindset, and Entrepreneurial Skills. The study also measure team behavior from students' perception to separate the business continuation from learning outcome perception.

\section{Results and Discussion}

\section{Demographic Analysis}

International Business Management students divided into two big major. One is delivered using English and designated for International Class (IBM-IC), the other $82.55 \%$ delivered using Indonesian language (IBM-RC). Both using the same entrepreneurship education curriculum and use the same intervention treatment. Table-4 showed the demographic of the respondents. It will also show that $9.19 \%$ of the student's businesses no longer continue to the next semester. The reason might be because of the business validation didn't goes well or 
the team decided to quit and they go separately to create another business project with different partners. The majority age respondents are the age of $18(37.71 \%)$ and $19(53.28 \%)$.

Tabel 6. Respondent's Profile

\begin{tabular}{lcr}
\hline Age & $\mathrm{N}$ & Percentage \\
\hline 17 & 7 & $1.31 \%$ \\
18 & 201 & $37.71 \%$ \\
19 & 284 & $53.28 \%$ \\
20 & 35 & $6.57 \%$ \\
21 & 5 & $0.94 \%$ \\
22 & 1 & $0.19 \%$ \\
TOTAL & 533 & \\
\hline Major & $\mathrm{N}$ & Percentage \\
\hline IBM RC & 440 & $82.55 \%$ \\
IBM IC & 93 & $17.45 \%$ \\
TOTAL & 533 & \\
\hline Business Continuation & $\mathrm{N}$ & Percentage \\
\hline Business Continue to Next Semester & 484 & $90.81 \%$ \\
Business Discontinue to the Next & \multicolumn{3}{|}{} \\
Semester & 49 & $9.19 \%$ \\
TOTAL & 533 & \\
\hline
\end{tabular}

The overall perception from the students to Entrepreneurial Venture Creation learning outcome is in high/positive level (4.58). Students agree that Entrepreneurial Venture Creation enhances their entrepreneurial knowledge (4.59), inspires their entrepreneurial mindset (4.571) and finally, improve their entrepreneurial skill (4.576). Their overall mean of team behavior perception is also showing in high/positive level, but with higher standard deviation. This means, their perception is more diverse when it comes to team behavior. This can be seen in Tabel-5.The result proves that entrepreneurship education enables the acquisition of entrepreneurial knowledge, skills, attitudes and behaviours (Pulka, Aminu, and Rikwentishe, 2015), even in the middle of pandemic and half of the course has been done online. This result showed a strong indication that Entrepreneurial Venture Creation curriculum is one of an effective entrepreneurship education curricula that can be deploy in offline and online classroom. In the middle of covid-19, the students' perception towards the learning outcome is still quite high with mean more than 4,5 range. The result also better than the result study in Public University in Malaysia that performed by Othman \& Othman (2017). However, the respondents in Public University in Malaysia are more diverse.

Tabel 7. Overall Perceived Learning Outcome and Team Behaviour

\begin{tabular}{lllll}
\hline & $\mathrm{N}$ & $\mathrm{M}$ & $\mathrm{SD}$ & Level \\
\hline Entrepreneurial Knowledge & 533 & 4.5947 & 0.4515 & high/positive \\
Entrepreneurial Mindset & 533 & 4.5715 & 0.4993 & high/positive \\
\hline
\end{tabular}




\begin{tabular}{|c|c|c|c|c|}
\hline Entrepreneurial Skills & 533 & 4.5760 & 0.5067 & high/positive \\
\hline Overall Learning Outcome & 533 & 4.5837 & 0.4512 & high/positive \\
\hline & $\mathrm{N}$ & $\mathrm{M}$ & SD & Level \\
\hline Team Resources & 533 & 4.3241 & 0.6351 & high/positive \\
\hline $\begin{array}{l}\text { Team Trust and Reliability } \\
\text { Overall Perceived Team }\end{array}$ & 533 & 4.4157 & 0.6237 & high/positive \\
\hline Behaviour & 533 & 4.3912 & 0.6085 & high/positive \\
\hline
\end{tabular}

However, the data then divided into those who will continue their business to the next semester and not. With this data we can see how the perspective of team behavior mean drop into moderately high level (3.7551), yet the overall mean of Entrepreneurial Venture Creation learning outcome still in high/positive level. Tabel-6 provides the result of the overall data comparison that has been analyzed.

Tabel 8. Perceived Learning and Team Behavior Comparison

\begin{tabular}{|c|c|c|c|c|c|c|c|c|}
\hline & \multicolumn{4}{|c|}{ Business Continue } & \multicolumn{4}{|c|}{ Business Does Not Continue } \\
\hline & $\mathrm{N}$ & $\mathrm{M}$ & SD & Level & $\mathrm{N}$ & $\mathrm{M}$ & SD & Level \\
\hline Entrepreneurial & & & & & & & & \\
\hline Knowledge & 484 & 4.6022 & 0.4488 & high/positive & 49 & 4.5215 & 0.4753 & high/positive \\
\hline Entrepreneurial Mindset & 484 & 4.5793 & 0.4933 & high/positive & 49 & 4.4939 & 0.5539 & high/positive \\
\hline Entrepreneurial Skills & 484 & 4.5822 & 0.5002 & high/positive & 49 & 4.5143 & 0.5686 & high/positive \\
\hline Overall Learning Outcome & 484 & 4.5909 & 0.4470 & high/positive & 49 & 4.5124 & 0.4899 & $\begin{array}{l}\text { high/positive } \\
\text { Moderately }\end{array}$ \\
\hline Team Resources & 484 & 4.3833 & 0.5700 & high/positive & 49 & 3.7398 & 0.9042 & $\begin{array}{l}\text { High } \\
\text { Moderately }\end{array}$ \\
\hline $\begin{array}{l}\text { Team Trust and Reliability } \\
\text { Overall Perceived Team }\end{array}$ & 484 & 4.4820 & 0.5517 & high/positive & 49 & 3.7607 & 0.8757 & $\begin{array}{l}\text { High } \\
\text { Moderately }\end{array}$ \\
\hline Behavior & 484 & 4.4556 & 0.5371 & high/positive & 49 & 3.7551 & 0.8639 & High \\
\hline
\end{tabular}

The result help us to understand that students' perception of the overall learning outcome doesn't affected by their business continuation and how they perceived their team. Both learning outcome perception for students who wants to continue or discontinue their business are in 4,5 mean range. Students still believe they gain entrepreneurial knowledge, mindset and skills even thou in the process they have found that their team resourcestrust, and reliability is not as what they expected to be. For business that doesn't continue to the next semester showed more diverse perception into team behavior. Both mean of Team Resources and Team Trust are in 3.7 ranges with standard deviation from 0.8 to 0.9 . The standard deviation is definitely higher than perceived team behavior for business that will continue to the next semester.It is also possible that during online class, the teams that work remotely have a higher chance of having a distrust issue and internal problem. Considered this curriculum performed during the pandemic, and only 9,19\% decided to discontinue their business is quite extra ordinary. In other perspectives, consider the age of these students, their 
perspectives of the team shared resources is in high/positive level. This might not worked for any other university since the students profile might be different.

\section{E. Conclusion and Implications}

Coronavirus affected the traditional learning technique for scholarly establishments over the world. The organizations of schools, universities and colleges settled on online talks/classes as an elective method to continue delivers the education. Even though online learning is demonstrating useful to protect students and personnel's wellbeing in the midst of Coronavirus pandemic, in any case, it isn't as compelling as regular offline learning. Keep in mind that without Corona Virus, Entrepreneurship Education should continue innovate the education methodology to be innovative and use more technology and online platform in the future. Facing VUCA and global pandemic in 2020, Universitas Ciputra Surabaya known with its entrepreneurship education curricula, strive to deliver entrepreneurship education to students using online platform. Specifically for Entrepreneurial Venture Creation curriculum, that has been held for the first time in the middle of pandemic.

The result of this study showed that students perceived the learning outcome in terms of increasing entrepreneurial knowledge, inspires entrepreneurial mindset, and enhancing entrepreneurial competency is significantly high/positive. The result of this study contributes to trigger further studies that entrepreneurship education can be done through online platform. Further studies should consider another variables measurement such as learning methodology, facilitators' competency, and students' motivation to measure and to find factors that support online entrepreneurship education. Thisstudy also provides data on how students' team behavior that discontinue their business didn't significantly affect their perceived learning outcome. Other limitation from this study is that the student profile also not diverse enough which only covers business management students.

\section{References}

Adhikusuma, Agus D.\&Genoveva (2020). The Influence Of Entrepreneurial Culture In Indonesia Towards Business Students' Intention To Be An Entrepreneur. FIRM Journal of Management Studies.Vol 5(1).18-33.

Cakranegara, Pandu A.\& Runtuk, J. K. (2019). Efektivitas Kurikulum Entrepreneurship President University Terhadap Entrepreneural Interest, Knowledge, Dan Orientation Mahasiswa. FIRM Journal of Management Studies.Vol 4(1).18-39.

Cucinotta, D., \&Vanelli, M. (2020). WHO declares COVID-19 a pandemic.Acta BioMedica: AteneiParmensis. Vol. 91(1).157-160.

Dunne, D. \& Martin, R. (2006). Design thinking and how it will change management education: An interview and discussion. Academy of Management Learning and Education.512-523. 
Fatoki, Olawale\& Oni, Olabanji.(2014). Students' Perception of the Effectiveness of Entrepreneurship Education at a South African University.Mediterranean Journal of Social Sciences.5. 10.5901/mjss.2014.v5n20p585.

Fayolle, A., \&Gailly, B. (2013). The Impact of Entrepreneurship Education on Entrepreneurial Attitudes and Intention: Hysteresis and Persistence. Journal of Small Business Management, Vol. 53(1).75-93.

Fiore E., Sansone G., \&Paolucci E. (2019). Entrepreneurship Education in a Multidisciplinary Environment: Evidence from an Entrepreneurship Programme Held in Turin. Administrative Sciences, Vol. 9 (1). 28.

Hair.Jr., J. F., Black., W. C., Babin., B. J., Anderson., R. E., \&L.Tatham., R. (2006). Multivariant Data Analysis. New Jersey: Pearson International Edition.

Harper, D.A. (2008), "Towards a theory of entrepreneurial teams", Journal of Business Venturing, Vol. 23 (6).613-26.

Hytti U., Stenholm P., Heinonen J., \&Seikkula-Leino J. (2010). Perceived learning outcomes in entrepreneurship education: The impact of student motivation and team behavior. Education and Training,Vol. 52 (8/9).587-606.

Kassean, H., Vanevenhoven, J., Liguori, E., Winkel, D. E. (2015). Entrepreneurship education: A need for reflection, real-world experience and action. International Journal of Entrepreneurial Behavior \& Research, Vol. 21(5).690-708.

Liguori, E., \& Winkler, C. (2020). From Offline to Online: Challenges and Opportunities for Entrepreneurship Education Following the COVID-19 Pandemic. Entrepreneurship Education and Pedagogy, Vol. 3(4). 346-351.

McPherson, M. S., Bacow, L. S. (2015). Online higher education: Beyond the hype cycle. The Journal of Economic Perspectives, 29(4), 135-153.

Morris, M. H., Liguori, E. (2016). Teaching reason and the unreasonable.In Morris, M., Liguori, E. (Eds.), Annals of entrepreneurship education and pedagogy. Edward Elgar Publishing, Vol. 2. 14-22.

Neck, H. M., Greene, P. G., Brush, C. G. (Eds.). (2014). Teaching entrepreneurship: A practice-based approach. Edward Elgar Publishing.

Othman, Norasmah\& Othman, SitiHanisah (2017).The Perceptions of Public University Students of Entrepreneurship Education in Malaysia. International Business Management, Vol. 11(4). 865-873.

Pulka, B. M., Aminu, A. A., \&Rikwentishe, R. (2015). The Effects of Entrepreneurship Education on University students' Attitude and Entrepreneurial Intention. European Journal of Business and Management, Vol. 7(20).149-157. 
Seow, P.-S., Pan, G., \&Koh, G. (2019).Examining an experiential learning approach to prepare students for the volatile, uncertain, complex and ambiguous (VUCA) work environment.The International Journal of Management Education, 17(1).62-76. 